\title{
Diversifikasi Olahan Jamur Merang (Volvariella volvacea) sebagai Produk Makanan Bagi PKK Bungong Seulanga di Birem Rayeuk Aceh Timur
}

\author{
Indriaty ${ }^{1}$, Setyoko ${ }^{2}$, Marjanah $^{3}$, Ainul Mardiyah ${ }^{4}$ \\ 1,2,3 Fakultas FKIP, Universitas Samudra, ${ }^{4}$ Fakultas Pertanian, Universitas Samudra \\ e-mail: 1indriaty@unsam.ac.id, 2setyoko@unsam.ac.id, \\ 3marjanah.bio@unsam.ac.id, 4ainulmardiyah@unsam.ac.id
}

\begin{abstract}
Abstrak
Kegiatan Pengabdian Kepada Masyarakat (PKM) yang dilaksanakan melakukan diversifikasi olahan jamur merang (Volvariella volvacea) sebagai produk makanan yang dapat menyediakan sumber makanan sehat dan bergizi, serta dalam upaya peningkatan ekonomi keluarga bagi masyarakat PKK Bungong Seulanga di Gampong Birem Rayeuk Kecamatan Birem Bayeun Kabupaten Aceh Timur. Kegiatan ini dilaksanakan pada 26 Juni sampai dengan 3 Juli 2019. Pelaksanaan kegiatan Pengabdian kepada masyarakat di PKK Bungong Seulanga Aceh Timur terbagai menjadi 5 tahapan kegiatan: (1) tahap sosialisasi kegiatan, (2) tahap persiapan alat dan bahan yang digunakan, (3) tahap pelatihan diversifikasi jamur merang menjadi produk olahan: Bakso Jamur, Nugget Jamur dan Stik Jamur, (4) tahap pelatihan pemasaran dan pendampingan kewirausahaan, dan (5) tahap monitoring dan evaluasi kegiatan. Tujuan kegiatan ini memberikan pelatihan pengolahan diversifikasi olahan jamur merang menjadi berbagai produk makanan yang dapat dikonsumsi sehat dan bergizi. Serta, dapat menjadi sumber wirausaha baru bagi PKK Bugong Seulanga untuk meningkatkan pendapatan ekonomi keluarga.
\end{abstract}

Kata Kunci: Diversifikasi Jamur Merang, Produk makanan, Bungong Seulanga

\begin{abstract}
Community Service Activities (PKM) carried out diversified processed mushroom (Volvariella volvacea) as a food product that can provide healthy and nutritious food sources, as well as in family economic improvement efforts for the Bungong Seulanga PKK community in Birem Rayeuk Village, Birem Bayeun District, District East Aceh. This activity is carried out on June 26 to July 3, 2019. The implementation of community service activities in the Bungong Seulanga PKK in East Aceh is divided into 5 stages of activities: (1) the stage of dissemination of activities, (2) preparation phase of tools and materials used, (3) the stages of training diversification of mushroom into processed products: Mushroom Meatballs, Mushroom Nugget and Mushroom Sticks, (4) stages of marketing training and entrepreneurship assistance, and (5) monitoring and evaluation stages of activities. The purpose of this activity is to provide training in the diversification of processed mushroom processing into a variety of healthy and nutritious food products. And, it can be a new source of entrepreneurship for the Bugong Seulanga PKK to increase family economic income.
\end{abstract}

Keywords: Diversification of Merang Mushrooms, Food Products, Bungong Seulanga 


\section{JURNAL ABDIMAS BSI}

Jurnal Pengabdian Kepada Masyarakat

\section{Pendahuluan}

Kelompok PKK Bungong Seulanga merupakan suatu kelompok masyarakat yang terdiri dari ibu-ibu yang bejumlah 35 orang, sebagian besar berprofesi sebagai Petani, Peternak, dan Ibu Rumah Tangga yang berada di Gampong Birem Rayeuk Kecamatan Birem Bayeun kebutuhan keluarga memberikan dorongan yang kuat bagi kelompok PKK Bungong Seulanga dalam melalukan kegiatan-kegiatan yang bermanfaat. Masyarakat akan tetap bertahan dengan kondisi ekonomi yang fluktuatif, sehingga berbagai upaya masyarakat dalam menjaga kestabilan ekonomi dikeluarganya.

Kelompok PKK Bungong Seulanga sangat aktif dan memiliki minat yang tinggi dalam melaksanakan kegiatan yang dapat meningkatkan ekonomi kesejahteraan keluarga. Hasil tindaklajut kegiatan pengabdian sebelumnya yang telah dilakukan kelompok tani Rakan Tani di Gampong Paya Bili Kecamatan Birem Bayeun Kabupaten Aceh Timur dalam pelatihan dan pendampingan budidaya Jamur Merang (Volvariella volvacea) bemedia jerami padi. Jamur merang merupakan salah satu spesies jamur berwarna putih hingga hitam, berbentuk bulat pada stadium primordial dan berbentuk payung pada stadium dewasa. Jamur merang dapat tumbuh dalam media seperti limbah tandan kosong sawit dan jerami padi (Yuliani, 2009).

Hasil budidaya jamur merang yang dilakukan kelompok tani Rakan Tani menghasilkan jumlah jamur merang yang dapat dikonsumsi sesuai dengan kebutuhan masyarakat setempat. Selain itu, hasil produksi jamur merang dari kelompok tani Rakan Tani juga sudah dipasarkan kepada masyarakat di Gampong Birem Rayeuk mengingat akses dari kedua desa ini sangat dekat. Ketersediaan jamur merang yang cukup banyak dipasok dari kelompok tani Rakan Tani di Gampong Paya Bili setiap hari dikonsumsi menjadi sumber makanan pendamping bagi masyarakat.

Jamur merang (Volvariella volvacea) yang tersedia dapat dikembangkan menjadi diversifikasi olahan makanan (Sinaga, 2007). Jamur merang dapat dikonsumsi bagi masyarakat menjadi produk makanan sehat dan bergizi melalui proses kebersihan sanitasi dan hygienes dalam pengolahan makanan. Jamur merang mengandung volva toksin dan flamutoksin yang dapat memacu kerja jantung (cardiac tonic) dan berguna bagi penderita fungsi gangguan jantung (Ichsan dan Ariska, 2011). Jamur merang kaya akan kandungan protein, kabrobohidrat, lemak, kalsium, fosfor dan zat-zat lainnya seperti serat pangan, thiamin, riboflavin, niacin, dan kalsium serta dan mineral (Gunawan, 2000). Selain itu, akan memberikan suplai makanan produk olahan jamur sebagai makanan keluarga yang dapat disajikan sebagai menu suplementer variatif yang kaya akan gizi (Syariefa, 2012).

Peningkatan pengetahuan dan keterampilan dalam meningkatkan ekonomi keluarga melalui pelatihan kewirausahaan dan pemasaran produk olahan jamur merang. Tujuan dalam pengabdian kepada masyarakat ini memberikan pelatihan dan pembekalan dan pendampingan ibu-ibu PKK Bungong Seulanga mengenail diversifikasi olahan jamur merang meliputi pembuatan makanan keluarga sehat dan bergizi meliputi pembuatan bakso jamur, nugget jamur dan stik jamur. Makanan 


\section{JURNAL ABDIMAS BSI}

Jurnal Pengabdian Kepada Masyarakat

olahan dibuat berbahan dasar jamur merang yang dibudidaya langsung oleh masyrakat. Pelatihan diversifikasi olahan jamur bertujuan untuk memberikan pengetahuan kepada masyrakat produk olahan makanan yng sehat dan bergizi. Serta mendorong masyarakat untuk berwirausaha khususnya ibu-ibu PKK Bungong Seulanga di Gampong Birem Rayeuk. Terbukanya wirausaha yang baru akan dapat meningkatkan pendapatan ekonomi keluarga.

\section{Metode}

Metode pelaksanaan kegiatan pengabdian kepada masyarakat (PKM) terdiri dari 5 tahapan kegiatan: (1) tahap sosialisasi kegiatan, (2) tahap persiapan alat dan bahan yang digunakan, (3) tahap pelatihan diversifikasi jamur merang menjadi produk olahan: Bakso Jamur, Nugget Jamur dan Stik Jamur, (4) tahap pelatihan pemasaran dan pendampingan kewirausahaan, dan (5) tahap monitoring dan evaluasi kegiatan.

Peran Tim PKM dan Partisipasi Mitra PKK Bungong Seulanga dijelaskan sebagai berikut: (1) Peran Tim PKM: (a) Memberikan materi sosialisasi kegiatan PKM, (b) Melakukan inventarisasi kebutuhan alat dan bahan kegiatan, (c) pelatihan diversifikasi olahan jamur merang, (d) pendampingan wirausaha dan pemasaran produk, (e) monitoring dan evaluasi kegiatan. Peran mitra PKK Bungong Seulanga: (a) Menyediakan waktu, tempat dan tenaga selama kegiatan, (b) berperan aktif dan partisiapatif anggota kelompok dalam kegiatan pengabdian kepada masyarakat.

\section{Hasil dan Pembahasan}

Pelaksanan program pengabdian kepada masyarakat dilaksanakan pada 26 Juni sampai dengan 3 Juli 2019 di PKK Bungong Seulanga di Gampong Birem Rayeuk Kecamatan Birem Bayeun Kabupaten Aceh Timur. Tahapan kegiatan: (1) sosialisasi kegiatan, (2) persiapan alat dan bahan yang digunakan, (3) pelatihan diversifikasi jamur merang menjadi produk olahan: Bakso Jamur, Nugget Jamur dan Stik Jamur, (4) pelatihan pemasaran dan pendampingan kewirausahaan, dan (5) monitoring dan evaluasi kegiatan.

\section{Tahap Sosialisasi Kegiatan}

Tahap sosialisasi dilakukan oleh Tim PKM bersama dengan mitra PKK Bungong Seulanga dilaksanakan di rumah Warga di Gampong Birem Rayeuk Kecamatan Birem Bayeun Kabupaten Aceh Timur. Pada kegiatan ini dibuka langsung oleh Tim PKM. Tim Mitra dihadiri oleh 35 orang PKK Bungong Seulanga. Tim pengabdian pada masyarakat dengan menjelaskan tujuan kegiatan pengabdian masyarakat yang dilakukan dengan rangkaian kegiatan meliputi tentang olahan jamur merang, wirausaha dan pemasaran hasil olahan, dilaksanakan tanya jawab dan penutup.

Kegiatan Sosialisasi dilakukan agar masyarakat cepat tanggap terhadap kegiatan pengabdian masyarakat yang dilakukan. Hal ini dilakukan sebagai upaya dalam menstimulus mitra dalam pelaksanaan kegiatan. Selain itu mitra dapat memperoleh pengetahuan dari kegiatan yang dilaksanakan.Menurut Dandirwalu, et al., (2020) 


\section{JURNAL ABDIMAS BSI}

Jurnal Pengabdian Kepada Masyarakat

Dampak Sosialiasi dapat meningkatkan pengetahuan dan pemahaman dari kegiatan yang dilakukan.

\section{Tahap Persiapan Alat dan Bahan}

Tahapan persiapan dilaksanakan dengan menginventarisasi persiapan alat dan bahan yang akan digunakan. Inventarisasi dilakukan dengan menyiapkan alat dan bahan yang sudah tersedia atau dengan membeli perlangkapan tambahan. Adapun bahan alat dan bahan yang digunakan seperti: kompos gas, kukusan, talam, baskom, pengaduk gorengan, kuali, mangkok, sendok, spanduk kegiatan, Jamur merang, tepung terigu, tepung panir, tepung kanji, Bumbu dapur (wortel, kayu manis, lada, kentang, daun sop), mie jagung, mie putih, telur, daging ayam, air bersih. Sebagian besar alat dan bahan yang disediakan oleh tim PKM dan beberapa alat dibantu oleh mitra.

\section{Tahap Pelatihan Diversifikasi Jamur Merang}

Tahapan pelatihan dilakukan dengan tutorial dan simulasi langsung. Tim PKM memberikan Brosur panduan tatacara pengolahan jamur merang meliputi; prosedur pengolahan Bakso jamur, Nugget jamur, dan Stik jamur kepada ibu-ibu PKK Bungong Suelanga. Brosur Panduan Pengolahan diberikan untuk mempermudah mitra dalam mempelajari proses pengolahannya dan menjadi sumber bacaan pada saat melakukan secara mandiri

Kegiatan awal dilakukan dengan menjelaskan deskripsi jamur, kandungan gizi dan manfaat bagi tubuh dalam mengkonsumsi jamur sebagai sumber makanan tambahan di keluarga. Selanjutnya memberikan penjelasan pembutan jamur merang menjadi Bakso jamur, prosesnya dilakukan melalui pencampuran bahan dasar sampai dengan pembutan bumbu resep dan mengukus pentol bakso jamur. Hasil pembuatan pentol bakso jamur langsung dapat dinikmati dan dicicipi oleh mitra ibu-ibu PKK Bungong Seulanga.

Pembuatan Nugget jamur, pada tahapan ini ibu-ibu PKK Bungong Seulanga semakin antusias dan aktif dalam membagi tugas turut dalam pembuatan Nugget. Tim PKM memberikan penjelasan mengenai struktur kandungan dalam jamur banyak mengandung air, sehingga dalam pembuatan adonan tidak diperlu menambahkan air.

Adonan bahan dasar pembuatan nugget agar tidak telalu banyak menambahkan air menghindari adonan dengan tekstur lembek dan berair sulit untuk dicetak sesuai dengan keinginan. Kegiatan selanjutnya membuat Stik jamur dengan menggunakan mesin Lumpia. Adonan yang dibuat harus tekstur semi padas sehingga dapat menghasilkan stik jamur yang diinginkan. Hasil pembuatan stik jamur mendorong ibu-ibu PKK Bungong Seulanga untuk mencoba sendiri secara beragantian dengan variasi cetakan berbeda. Olahan makanan bahan dasar jamur ini sangat sedap dan gurih, mengingat jamur juga sebagai penyedap alami. Diversifikasi olahan jamur merang menjadi tiga macam Bakso Jamur, Nugget Jamur dan Stik Jamur. 


\section{JURNAL ABDIMAS BSI}

Jurnal Pengabdian Kepada Masyarakat

\section{Tahap Pelatihan Pemasaran dan Wirausaha}

Pelatihan pemasaran dan wirausaha merupakan tahapan pendukung dari program pengabdian kepada masyarakat. Pelatihan pemasaran dan wirausaha diberikan kepada mitra PKK Bungong Suelanga masih dalam ketegori pengetahuan dasar. Hal ini dilakukan oleh Tim PKM untuk menstimulasi mitra agar dapat merintis usaha baru melalui produk diversifikasi olahan jamur merang. Mitra berdiksusi aktif dengan tim PKM terutama dikaitkan dengan kondisi modal usaha dan sasaran konsumen.

Pemasaran dapat dilakukan secara face to face terhadap konsumen dapat dilakukan dipusat perbelanjaan sepeti di pasar atau pertokoan. Pemasaran juga dapat dilakukan secara online melalui media sosial atau market online, sehingga produk dagangan dapat dipasarkan secara meluas. Pemasaran suatu nilai produk dapat dilakukan dengan mengguakan e-commerce, yang sudah menjadi kebutuhan bagi masyarkat dengan berjualan secara mandiri (Juliana, et al., (2020).

\section{Tahap Monitoring dan Evaluasi}

Kegiatan monitoring dan evaluasi pelaksanaan program ini dilakukan oleh tim PKM dalam rangka mengukur indeks keberhasilan program pengabdian kepada masyarakat. Monitoring dilakukan setelah pelaksaaan pelatihan diversifikasi olahan makanan dan pelatihan pemasaran dan wirausaha. Mitra PKK Bungong Seulanga sebagian besar sudah membuat olahan diversifikasi jamur merang dirumah masingmasing dan menjadikan berbagai variasi kebutuhan makanan sebagai menu lauk pauk dalam keluarga.

Tim PKM juga menemukan hasil monitoring Mitra PKK Bungong Seulanga masih belum sepenuh bisa merintis usaha baru dalam produksi olahan makanan jamur. Mitra juga masih kesulitan untuk memasarkan hasil olahan makanan diversifikasi jamur merang, sehingga diperlukan pendampingan secara khusus dan lebih lanjut dalam membuat merintis wirausaha baru. Evaluasi kegiatan program dilakukan dengan pendampingan khusus kepada mitra PKK Bungong Seulanga dalam merintis usaha baru. Mulai dari modal usaha bergulir, manajemen organisasi kelompok, Strategi pemasaran produk dan perizinan PIRT produk olahan. Diversifikasi olahan jamur bisa menjanjikan dalam penjualan kedepan, melihat jamur sangat diminati sebagai aneka makanan masyarakat sebagai makanan cemilan atau lauk pauk. Budidaya jamur tiram dan olahannya memberi dampak positif bagi masyarakat dan jamur memiliki prospek dan peluang besar dipasaran (Zulfarina, et al., 2019). 


\section{JURNAL ABDIMAS BSI}

\section{Jurnal Pengabdian Kepada Masyarakat}

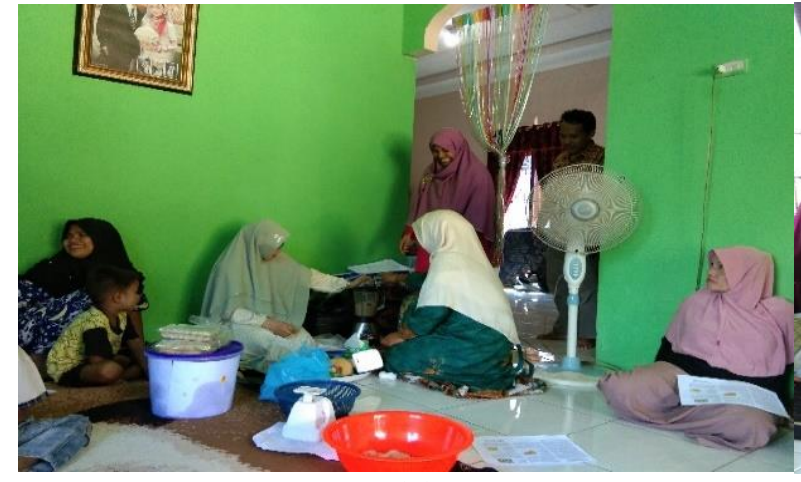

(a)

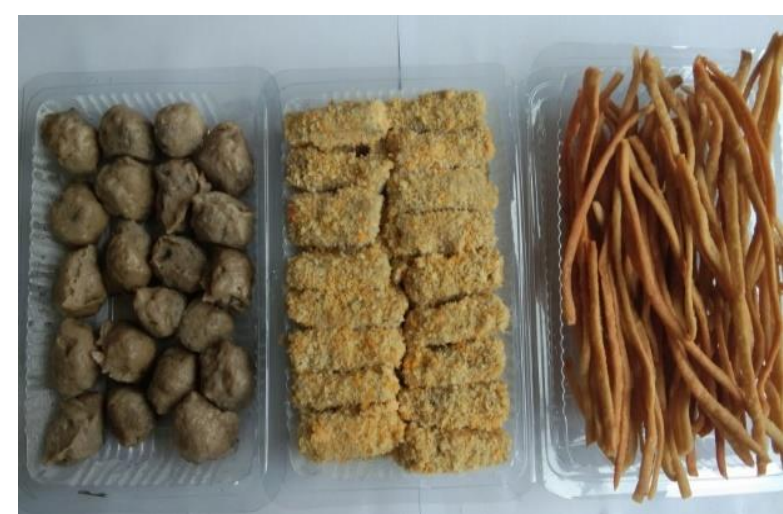

(c)

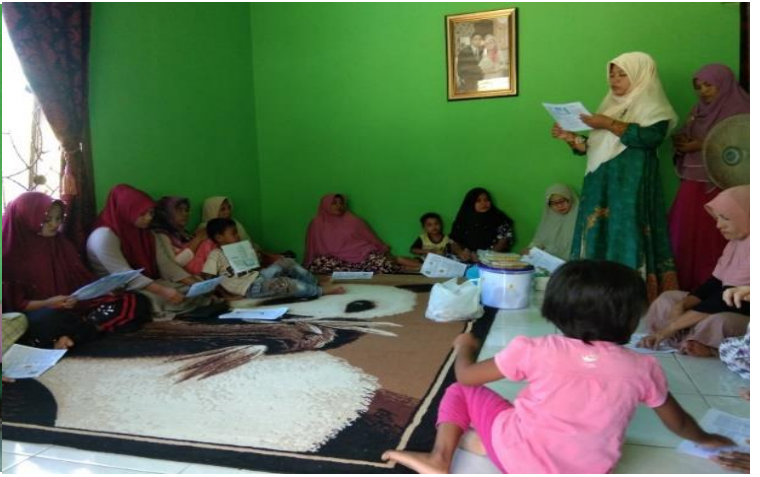

(b)

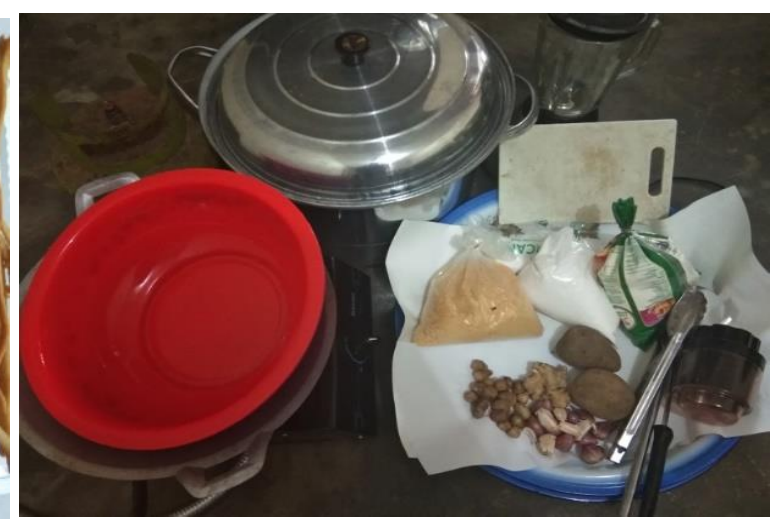

(d)

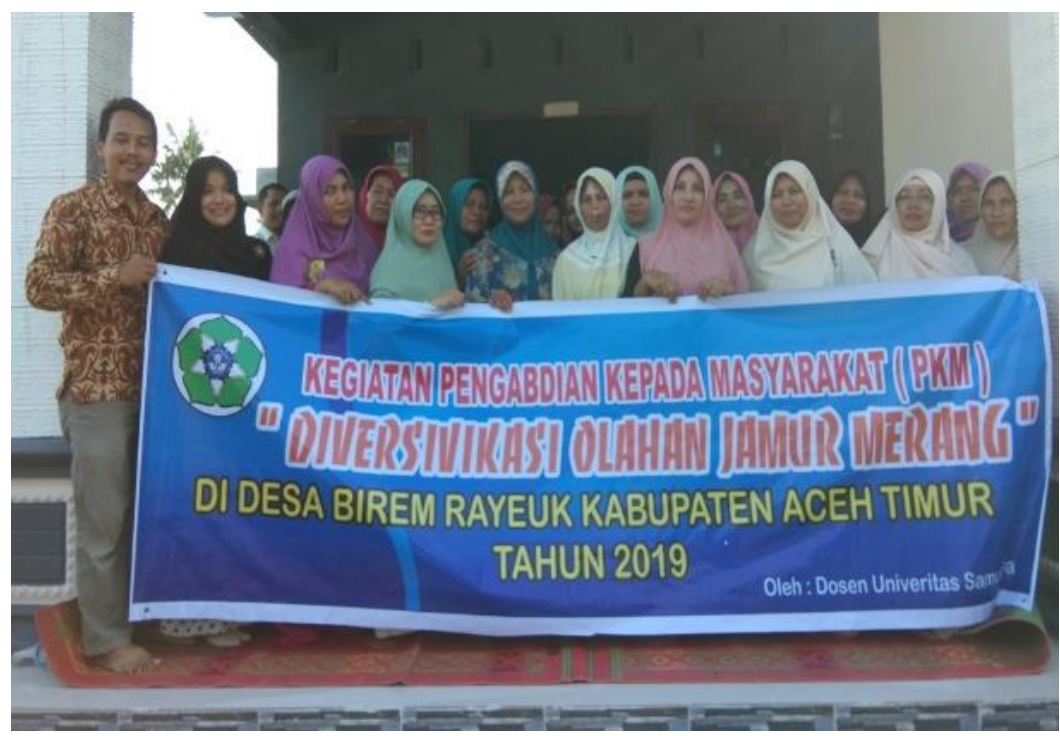

(e)

Sumber: dokumen Penulis Tim PKM 2019)

Gambar 1. (a) Sosialiasi Kegiatan, (b) Pelatihan Diversifikasi Jamur Merang; (c) Alat dan bahan yang digunakan, (d) Hasil Diversifikasi Jamur (e) Foto bersama Tim dengan Mitra 


\section{JURNAL ABDIMAS BSI}

Jurnal Pengabdian Kepada Masyarakat

\section{Simpulan dan Rekomendasi}

Pengabdian Kepada Masyarakat dilaksanakan di PKK Bungong Seulanga Gampong Birem Rayeuk Kecamatan Birem Bayeun Kabupaten Aceh Timur dapat disimpulkan bahwa mitra Jamur dapat mengolah aneka diversifikasi produk makanan dari bahan dasar jamur merang. Mitra dapat berwirausaha produk olahan jamur merang secara berkelompok dilakukan bersama dengan modal bergulir skala mikro. Perlu penguatan mitra untuk memasarkan Produk olahan jamur merang belum ada izin PIRT dan rendahnya minat daya beli masyarakat terhadap produk jamur merang.

Hasil rekomendasi dalam kegiatan progam ini, perlu ada izin P-IRT produk diversifikasi olahan jamur merang. Produk olahan yang dipasarkan perlu pengemasan (Pack) yang baik dan menarik, sehingga dapat menerarik konsumen dan dapat dipasarkan secara luas sperti di toko atau swalayan (market).

\section{Penghargaan}

Ucapan terimakasih penulis kepada LPPM dan PM Univesitas Samudra, Civitas Akademika Universitas Samudra, Mitra Bungong Seulanga dan Seluruh Pihak Terkait yang membantu kegiatan Pengabdian Kepada Masyrakat. Kegiatan ini merupakan Hibah Pengabdian Kepada Masyarakat Pendanaan Internal LPPM dan PM Universitas Samudra tahun 2019.

\section{Daftar Pustaka}

Dandirwalu, R., Persulessy, G., Hutubey, I., Wacanno, G., Sari, N., Putri, D \& Latuputty, F. 2020. Sosialisasi Dan Pelatihan Badan Usaha Milik Negeri Lowpano Sebagai Penyokong Kemandirian Negeri Tehua. Jurnal Abdimas BSI: Jurnal Pengabdian Kepada Masyarakat, 3 (2).p. 93-101.

Ichsan, C. N. Harun, F., dan Ariska, N. 2011. Karakteristik pertumbuhan dan hasil jamur merang (Volvariella volvaceae L) Pada media tanam dan konsentrasi pupuk biogreen yang berbeda. Jurnal Floratek (6) p. 171 - 180

Juliana, Maleachi, s., Yulisua, K.G \& Situmorang, J. 2020. Pelatihan Pembuatan Salad Sayur Hidroponik dan Cara Pemasaran yang Tepat dalam E-Commerce. Jurnal Abdimas BSI: Jurnal Pengabdian Kepada Masyarakat, 3 (2).p. 208-216.

Gunawan, A.W. 2000. Usaha Pembibitan Jamur. Jakarta: Penebar Swadaya.

Sinaga, M.S. 2007. Jamur Merang dan Budidayanya. Jakarta: Penebar Swadaya

Syariefa E, dkk. 2012. Jamur merang. Depok: PT Trubus Syawadaya. 


\section{JURNAL ABDIMAS BSI}

Jurnal Pengabdian Kepada Masyarakat

Yuliani F. 2009. Pertumbuhan dan produksi jamur merang (Volvariella volvaceae) yang ditanam pada media jerami, blotong dan ampas tebu dengan berbagai frekwensi penyiraman. Jurnal Sains dan Teknologi. 2 (1). p.1-15.

Zulfarina, Suryawati, E., Yustina, Putra, R \& Taufik, H. 2019. Pertumbuhan dan produksi jamur merang (Volvariella volvaceae) yang ditanam pada media jerami, blotong dan ampas tebu dengan berbagai frekwensi penyiraman. Jurnal Pengabdian Kepada Masyarakat: Indonesia Journal of Community Engagement, 5 (3). p.358-370. 